\title{
Analisis Kesalahan Berbahasa Bidang Morfologi pada Portal Radar Solo Tema Covid-19
}

\section{Septi Wulan Sari ${ }^{*}$ \\ Afifah Nuur Qoryah ${ }^{1}$ \\ Oky Yahya Aprilia ${ }^{1}$ \\ ${ }^{1}$ Institut Agama Islam Negeri Surakarta, Surakarta, Jawa Tengah, Indonesia \\ *email: septiwulansari1999@gmail.com}

Received: 18 Mei 2020

Accepted: 30 September 2020

Published: 30 September 2020

doi: $10.22236 /$ imajeri.v3i1.4996

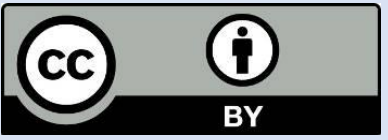

(C) 2020 Oleh authors. Lisensi Imajeri: Jurnal Pendidikan Bahasa dan Sastra Indonesia, Uhamka, Jakarta. Artikel ini bersifat open access yang didistribusikan di bawah syarat dan ketentuan Creative Commons Attribution (CC-BY) license.

(http://creativecommons.org/licenses/by/4.0/).

\section{Abstrak}

Radar Solo merupakan perusahaan jurnalistik yang berada di Solo. Berita disajikan melalui dua media yaitu, cetak dan publikasi melalui portal website dan media sosial lainnya. Sebagai media penyalur berita kepada pendengar dan pembaca tentu Radar Solo tidak luput dari kesalahan berbahasa dalam menulis dan menyiarkan berita. Untuk tujuan penelitian ini adalah untuk mendeskripsikan bentuk-bentuk kesalahan berbahasa bidang morfologi dalam penulisan berita di Radar Solo dengan tema Covid-19. Peneliti fokus untuk mengkaji beritaberita yang dipublikasikan pada bulan Maret tentang isu Covid19. Jenis penelitian ini adalah deskriptif kualitatif. Teknik yang digunakan dalam penelitian ini adalah membaca dan menulis. Hasil dari penelitian ini adalah kesalahan berbahasa bidang morfologi meliputi 1) Kesalahan penghilangan prefiks me- dan ber-, 2) Kesalahan penghilangan sufiks —an dan — kan, 3) Bunyi yang tidak diluluhkan, 4) Penggunaan afiks yang tidak tepat, 5) Peluluhan bunyi yang seharusnya tidak luluh. Dengan adanya penelitian ini diharapkan bisa menjadi evaluasi untuk lebih teliti dalam menuliskan berita khususnya pada bidang morfologi.

Kata kunci: Kesalahan Berbahasa; Morfologi; Daring; Covid-19, Media Massa

\section{Abstract}

Radar Solo is a journalism company based in Solo. News is presented through two media, namely, print and publication through a website portal and other social media. As a medium for distributing news to listeners and readers, of course Radar Solo is not free from language errors in writing and broadcasting news. For the purpose of this study is to describe the forms of language errors in morphology in writing news on Radar Solo with the theme Covid-19. Researchers focus on studying the news published in March about the Covid-19 issue. This type of research is descriptive qualitative. The techniques used in this study were reading and writing. The results of this study are language errors in the field of morphology including 1) errors in removing the prefixes of me and ber-, 2) errors in removing the suffixes -an and -kan, 3) sound that is not obliterated, 4) using inappropriate affixes, 5) pulverizing sounds that shouldn't melt. With this research, it is hoped that it can become a more thorough evaluation in writing news, especially in the field of morphology.

Key words: Language Error; Morphology; Online; Covid-19, Mass Media 


\section{PENDAHULUAN}

Berita merupakan bagian penting bagi kehidupan manusia, dimana berita mampu menyediakan banyak informasi setiap harinya (Kusumaningrat \& Kusumaningrat, 2009; Rahardi, 2006). Penyajian berita sehari-hari beragam bidangnya seperti bidang sosial, budaya, politik, hukum, dan lain-lain. Berita saat ini tidak hanya dikemas dalam bentuk cetak tetapi juga dalam bentuk daring di portal yang dapat diakses dengan mudah oleh banyak masyarakat. Berita daring memberikan informasi yang cenderung ringkas serta selalu aktual menyajikan peristiwa yang ada di masyarakat. Penyajian berita daring ini tentunya sangat menguntungkan bagi masyarakat karena dapat memperoleh informasi dengan cepat tanpa harus mencari penjual koran dan mengeluarkan uang sepersen pun (Hadi, 2009).

Dalam penulisan berita mesti memperhatikan ejaan dan kaidah kebahasaan Indonesia (Halim, 2015; Sari, 2014). Hal ini dikarenakan berita merupakan tulisan yang dapat mempengaruhi khalayak masyarakat sehingga tanpa disadari kesalahan penggunaan bahasa yang digunakan oleh berita dapat menjadi hal lumrah di masyarakat yang dapat menyebabkan adanya pergeseran penggunaan bahasa Indonesia. Tentu lah hal ini sangat disayangkan terlebih berita sudah menjadi makanan pokok bagi kehidupan manusia.

Berita yang menjadi sorotan saat ini adalah pemberitaan eksklusif mengenai pandemic Korona atau dalam istilah ilmiahnya Covid-19. Berita-berita korona ini tentu menjadi focus utama masyarakat dunia. World Health Organization (2020) menyebutkan penyakit virus Korona (COVID-19) adalah penyakit menular yang disebabkan oleh tipe virus Korona yang baru ditemukan. Penyakit ini mengganggu saluran pernapasan ringan hingga berat baik bergejala maupun tidak dan orang-orang dengan penyakit bawaan lebih rentan terhadap virus ini. Virus Korona itu sendiri sekarang sudah menjadi momok bagi masyarakat, masyarakat berbodong-bondong melakukan pencegahan agar terhindar dari virus Korona. Salah satu cara pencegahan yang dilakukan oleh masyarakat yaitu dengan memantau berita secara intensif melalui program berita di televisi maupun berita di gawai masing-masing. Salah satu portal daring yang mengamati perkembangan virus korona hingga saat ini yaitu Radar Solo.

Radar Solo merupakan media penyalur berita di Karesidenan Surakarta khususnya berita daerah Solo, Wonogiri, Sragen, Sukoharjo, dan Karanganyar. Radar Solo hingga saat ini tidak hanya menyajikan berita melalui koran-koran harian melainkan juga menyajikan berita melalui portal daring yang bias diakses oleh semua masyarakat. Melalui portal berita tersebut masyarakat dapat lebih mudah menjangkau berbagai informasi khususnya beritaberita lokal yang dekat dengan masyarakat sekitar Solo.

Melalui maraknya penyajian perkembangan berita virus Korona, penulis memilih

judul “Analisis Kesalahan Berbahasa Bidang Morfologi pada Portal Radar Solo Tema Covid-19 Edisi Maret 2020" untuk mendeskripsikan wujud kesalahan berbahasa morfologi yang masih banyak ditemukan oleh penulis dalam kurun waktu sebulan tersebut. Sejalan dengan penelitian yang dilakukan oleh Sari (2019) telah dilakukan analisis kesalahan berbahasa pada tataran kesalahan ejaan, sintaksis, semantik, morfologi, dan fonologi. Pada analisis kesalahan morfologi hanya ditemukan kesalahan afiksasi. Sehingga, kesalahan morfologi lebih rinci akan dibahas pada jurnal ini. Penelitian relevan lainnya dilakukan oleh Wijayanti (2014) disebutkan bahwasanya ditemukan kesalahan morfologi prefiks dan sufiks 
pada karangan narasi siswa. Sedangkan, pada penelitian ini lebih difokuskan terhadap kesalahan morfologi pada portal berita dimana para penulis berita lebih profesional dalam menulis berita dengan bahasa yang baik dan benar.

Berdasarkan data temuan dan hasil analisis dalam penelitian ini bisa dijadikan sebagai rujukan untuk digunakan pada penelitian selanjutnya. Serta penelitian ini dapat dijadikan rujukan dalam mengembangkan pengajalan dan pembelajaran bahasa khususnya ragam bahasa formal, dimana penulisan bahasa Indonesia yang baik dan benar sangat penting dalam penulisan berita.

Analisis kesalahan berbahasa merupakan kajian menganalisis penggunaan bahasa Indonesia yang melenceng dari penggunaan bahasa tersebut (Nurwicaksono \& Amelia, 2018). Analisis kesalahan berbahasa menjadi kajian yang banyak dilakukan oleh para civitas akademik baik mahasiswa maupun dosen apalagi yang berkaitan dengan media massa dengan berbagai perspektif (Dawa, Kaleka, \& Pingge, 2020; Febriyanti, 2020; Nisa, 2018; Sari, 2014; Sari \& Nurcahyo, 2019). Analisis kesalahan berbahasa ini dilakukan guna memberikan sajian penggunaan bahasa Indonesia yang baik khususnya penggunaan bahasa Indonesia dalam bidang formal seperti dalam karya ilmiah, jurnal, skripsi, dan lain-lain. Menurut Tarigan (1990) kesalahan berbahasa memiliki dua istilah, yang pertama adalah error (kesalahan) dan mistake (kekeliruan). Kesalahan yaitu penggunaan bahasa yang melanggar kaidah penggunaan tata bahasa, sedangkan kekeliruan adalah penggunaan kata yang tidak sesuai dengan keadaan atau kondisi tertentu.Salah satu kajian analisis kesalahan berbahasa adalah bidang kesalahan tataran morfologi.

Morfologi merupakan salah satu kajian dalam analisis kesalahan berbahasa. Morfologi sendiri masuk ke dalam lingkup kajian linguistik. Menurut Martinet (1987) dalam Chaer (2012) linguistik adalah kajian keilmuan bahasa yang dipakai oleh manusia. Manusia sebagai makhluk sosial perlu adanya bentuk komunikasi dan sejatinya komunikasi dapat terjadi antarmanusia apabila terdapat bahasa di dalamnya. Sedangkan morfologi itu sendiri merupakan wujud dari penggunaan bahasa yang memperhatikan pembentukan struktur katakata menjadi kalimat yang dapat berubah-berubah sesuai dengan jenis kata dan makna yang dimaksudkan oleh penulis (Wijayanti, 2014). Morfologi penting dalam kajian penggunaan bahasa karena morfologi itu sendiri menjadi dasar dari pembentukan kata, klausa, frase, sampai tingkatan pembentukan kalimat itu sendiri. Maka dari itu, morfologi menjadi salah satu kajian penting dalam analisis kesalahan berbahasa (Abdul, 2008).

Kajian analisis kesalahan morfologi ini dapat ditemukan dalam berbagai berita yang ada di koran khususnya Koran Radar Solo yang tidak hanya mencetak koran dalam bentuk kertas, tetapi juga mengunggah berita melalui portal Radar Solo.

\section{METODE}

Metode penelitian yang digunakan dalam penelitian ini adalah metode penelitian kualitatif. Menurut Agustina \& Oktavia (2019) penggunaan penelitian kualitatif didasarkan pada dua pertimbangan yaitu pengembangan konsep atas data yang diperoleh dan penelitian ini bersifat deskriptif. Peneliti mengolah data deskripsi secara sistematis, berdasarkan fakta, dan menghubungkannya dengan bidang ilmu yang ada. 
Data yang digunakan dalam penelitian ini adalah kesalahan berbahasa bidang morfologi pada website Radar Solo tema Covid-19 edisi Maret 2020. Teknik yang dilakukan oleh penulis untuk menghimpun data adalah dengan membaca berita dari website Radar Solo dan mencatat kesalahan berbahasa untuk diklasifikasikan sesuai bidang morfologi. Langkahlangkah dalam mengklasifikasikan data dan kesalahan antara lain yaitu, 1) pengumpulan data, 2) mengidentifikasi kesalahan, 3) mengklasifikasikan kesalahan, dan 4) mengevaluasi kesalahan.

\section{HASIL DAN PEMBAHASAN}

Berdasarkan pengumpulan data yang dilakukan oleh penulis tentang analisis kesalahan berbahasa tataran morfologi pada portal website Radar Solo tema Covid-19 edisi Maret 2020. Kesalahan berbahasa tataran morfologi dapat digambarkan seperti berikut :

Kesalahan Penghilangan Prefiks Me-dan Ber-

Tabel 1 Penghilangan prefiks me- dan ber- pada berita Covid-19 Radar Solo

NO PUBLIKASI JUDUL BERITA

1.

3. 2020

4.

24 Maret

2020

5. 17 Maret 2020

2 Pasien Masuk Ruang Isolasi RSUD DR

Moewardi, Belum Pasti

Covid-19

2. 13 Maret

2020

Sudah 2 Hari Dinkes Solo

Lacak Jejak Pasien

Meninggal Positif Korona

Pojok Cuci Tangan di

Pasar Tradisional

Bupati Sukoharjo

Tetapkan Status KLB

IDI Solo bentuk satgas

corona virus, dukung

keterbukaan informasi
KALIMAT

KESALAHAN

“Tapi, sampel swab

tenggorokan kedua

pasien sudah dikirim ke

kemenkes. Tinggal

tunggu hasilnya"

"Sudah 2 hari Dinkes lacak

Solo lacak jejak pasien

meninggal positif

korona"

"Sejumlah pasar

lakukan

tradisional sudah

lakukan tindakan

prefentif mengantisipasi

penyebaran virus

korona (Covid-19)."

"Sebelumnya pasien ikuti

pernah ikuti outbond di

suatu tempat."

"...yang akhirnya bisa sinergi

sinergi dengan rencana

pemerintah dalam

penuntasan korona di

kota bengawan.." 
Data (1) "Tapi, sampel swab tenggorokan kedua pasien sudah dikirim ke kemenkes. Tinggal tunggu hasilnya"

Penggunaan kata tunggu pada kalimat tersebut kurang tepat karena kata tunggu kurang menunjukkan kata kerja tindakan. Kata tunggu lebih tepat digunakan apabila ada penambahan afiks (meN-) sehingga menjadi kata menunggu.Kata menunggu itu sendiri lebih menegaskan bahwasanya ada aktivitas menunggu didalam kalimat tersebut. Maka dari itu, pembenaran data (2) menjadi "Tapi, sampel swab tenggorokan kedua pasien sudah dikirim ke kemenkes. Tinggal menunggu hasilnya"

Data (2) “Sudah 2 hari Dinkes Solo lacak jejak pasien meninggal positif korona”

Penggunaan kata lacak pada kalimat tersebut kurang tepat karena kurang menunjukkan adanya kata kerja tindakan. Kata lacak lebih tepat digunakan apabila ada penambahan afiks (meN-) sehingga menjadi kata melacak. Kata melacak itu sendiri lebih menegaskan bahwasanya ada aktivitas melacak yang dilakukan oleh Dinas Kesehatan Solo. Sehingga pembenaran pada data (5) "Sudah 2 hari Dinkes Solo melacak jejak pasien meninggal positif korona"

Data (3) “Sejumlah pasar tradisional sudah lakukan tindakan prefentif mengantisipasi penyebaran virus korona (Covid-19)."

Penggunaan kata lakukan pada kalimat tersebut kurang tepat karena tidak baku dan tidak menunjukkan kata mengerjakan suatu hal. Kata lakukan lebih tepat digunakan apabila ada penambahan afiks (me-) sehingga menjadi kata melakukan.Kata melakukan memiliki arti mengerjakan atau melaksanakan sesuatu sebagai tindakan tanggap pasar tradisional untuk mencegah penyebaran Covid-19. Sehingga pembenaran pada data (6) "Sejumlah pasar tradisional sudah melakukan tindakan prefentif mengantisipasi penyebaran virus korona (Covid-19)."

Data (4) “...yang akhirnya bisa sinergi dengan rencana pemerintah dalam penuntasan korona di kota bengawan.."

Penggunaan kata sinergi pada kalimat tersebut kurang tepat karena tidak menunjukkan melakukan kegiatan.Kata sinergi lebih tepat digunakan apabila ada penambahan afiks (ber-) sehingga menjadi kata bersinergi.Kata bersinergi memiliki arti melakukan kegiatan atau operasi gabungan.Sehingga pembenaran pada data (8) “...yang akhirnya bisa bersinergi dengan rencana pemerintah dalam penuntasan korona di kota bengawan.."

Data (5) "Sebelumnya pasien pernah ikuti outbond di suatu tempat." 
Penggunaan kata ikuti pada kalimat tersebut kurang tepat karena tidak menunjukkan melakukan kegiatan. Kata ikuti lebih tepat digunakan apabila ada penambahan afiks (meng-) dan sufiks (-i) sehingga menjadi kata mengikuti. Kata mengikuti memiliki arti turut menyertai suatu kegiatan yaitu, outbond yang dilakukan oleh pasien sebelum terjangkit Covid-19.Sehingga pembenaran pada data (9) adalah "Sebelumnya pasien pernah mengikuti outbond di suatu tempat."

Kesalahan Penghilangan Sufiks —an dan — kan

Tabel 2. Penghilangan sufiks -an dan -kan pada berita Covid-19 Radar Solo

NO PUBLIKASI JUDUL BERITA

1.

1. 9 Maret $2020 \quad 2 \mathrm{~Pa}\left(\begin{array}{l}0 \\ \end{array}\right.$ Isolasi RSUD DR

Moewardi, Belum Pasti

Covid-19

2.

9 Maret 20202 Pasien Masuk Ruang Isolasi RSUD DR Moewardi, Belum Pasti Covid-19

3.

10 Maret 2020

Pasar Darurat Purwosari, Hanya Pedagang Aktif yang Difasilitasi

KALIMAT

KESALAHAN

ruang

kemudian masuk ke

ruang isolasi pada

Minggu (8/3)."

"Satu pasien

diantar

merupakan pasien dari

rumah sakit lain di

Solo, sementara satu

lainnya diantar oleh

keluarganya"

"Sugiyanto

barangan

mempersilakan

pedagang pada pekan

ini untuk men-display

barangan dagangan."

4. 17 Maret

Pojok Cuci Tangan di

Pasar Tradisional
“Di pasar legi, pojok dimodifikasi

cuci tangan berupa tong

plastik atau gallon yang

dimodifikasi dengan

keran air."

Data (1) "Kedua pasien kemudian masuk ke ruang isolasi pada Minggu (8/3)."

Penggunaan kata ruang pada kalimat tersebut kurang tepat karena kata ruang hanya menunjukkan tempat tertentu. Kata ruang lebih tepat digunakan apabila ada penambahan sufiks (-an) sehingga menjadi kata ruangan. Kata ruangan itu sendiri lebih menegaskan bahwasanya pasien akan dimasukkan ke dalam ruangan yang digunakan untuk isolasi. 
Pembenaran data (1) menjadi "Kedua pasien kemudian masuk ke ruangan isolasi pada Minggu (8/3)."

Data (2) "Satu pasien merupakan pasien dari rumah sakit lain di Solo, sementara satu lainnya diantar oleh keluarganya"

Penggunaan kata diantarpada kalimat tersebut kurang tepat karena kata diantartidak sesuai dengan dengan aturan atau kaidah bahasa Indonesia. Kesalahan tersebut terjadi karena penghilangan afiks khususnya penghilangan sufiks (-kan) pada kata diantar seharusnya ditulis diantarkan. Sehingga pembenaran pada data (3) adalah "Satu pasien merupakan pasien dari rumah sakit lain di Solo, sementara satu lainnya diantarkan oleh keluarganya"

Data (3) "Sugiyanto mempersilakan pedagang pada pecan ini untuk men-displaybarangan dagangan."

Penggunaan kata barangan pada kalimat tersebut kurang tepat karena terdapat penambahan sufiks (-an) yang seharusnya tidak perlu ditambahkan. Kata yang seharusnya dipakai adalah barang tanpa adanya penambahan sufiks (-an) karena pada kata berikutnya, yaitu dagangan sudah menunjukkan adanya penggunaan sufiks (-an). Terlebih lagi kata barang yang dimaksud lebih menunjukkan bentuk nominanya. Sehingga pembenaran pada data (4) adalah "Sugiyanto mempersilakan pedagang pada pecan ini untuk mendisplaybarang dagangan."

Data (4) “Di pasar legi, pojok cuci tangan berupa tong plastik atau galon yang dimodifikasi dengan keran air."

Penggunaan kata dimodifikasi pada kalimat tersebut kurang tepat karena tidak baku dan tidak menunjukkan keterangan melakukan sesuatu. Kata dimofikasi lebih tepat digunakan apabila ada penambahan afiks (kan-) sehingga menjadi kata dimodifikasikan.Kata dimodifikasikanmemiliki arti melakukan modifikasi terhadap suatu benda.Sehingga pembenaran pada data (7) "Di pasar legi, pojok cuci tangan berupa tong plastik atau galon yang dimodifikasikan dengan keran air." 


\section{Bunyi yang Seharusnya Luluh Tidak Diluluhkan}

Tabel 3. bunyi yang seharusnya luluh tidak diluluhkan pada berita Covid 19 Radar Solo

\section{NO PUBLIKASI JUDUL BERITA KALIMAT}

KESALAHAN

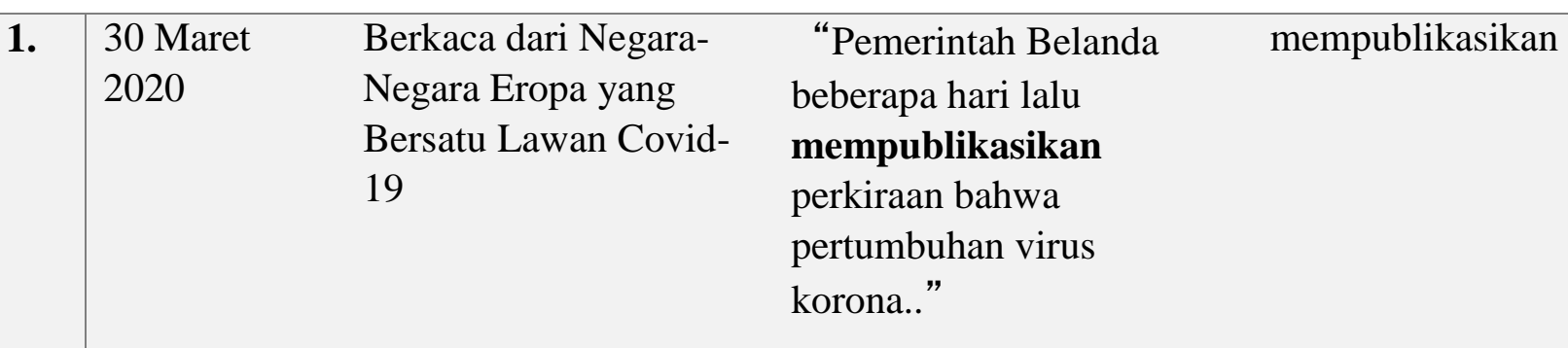

Data (10) "Pemerintah Belanda beberapa hari lalu mempublikasikan perkiraan bahwa pertumbuhan virus korona.."

Berdasarkan kalimat di atas terdapat kesalahan bunyi yang seharusnya luluh tidak diluluhkan pada kata mempublikasikan. Kata mempublikasikan lebih tepat digunakan apabila / $p /$ diluluhkan dengan tambahan prefiks (meN-) menjadi (mem-) karena diikuti oleh kata dasar publikasi sehingga menjadi memublikasikan. Kata memublikasikan disini memiliki arti menyebarluaskan berita tentang Covid 19 sehingga kalimat yang benar pada data (10) adalah "Pemerintah Belanda beberapa hari lalu memublikasikan perkiraan bahwa pertumbuhan virus korona..."

Penggunaan Afiks yang Tidak Tepat

Tabel 4. Penggunaan afiks yang tidak tepat pada berita Covid 19 Radar Solo

\section{NO PUBLIKASI JUDUL BERITA KALIMAT KESALAHAN}

\begin{tabular}{|c|c|c|c|c|}
\hline 1. & $\begin{array}{l}\text { 14 Maret } \\
2020\end{array}$ & $\begin{array}{l}\text { Antisipasi korona, pemkab } \\
\text { klaten putuskan } 14 \\
\text { kebijakan }\end{array}$ & $\begin{array}{l}\text { “Termasuk disiapkan } \\
\text { rumah sakit rujukan } \\
\text { nasional yakni RSUP } \\
\text { dr.Soeradji Tirtonegoro } \\
\text { Klaten” }\end{array}$ & Disiapkan \\
\hline 2. & $\begin{array}{l}17 \text { Maret } \\
2020\end{array}$ & $\begin{array}{l}\text { Pojok Cuci Tangan di } \\
\text { Pasar Tradisional }\end{array}$ & $\begin{array}{l}\text { “Ke depannya akan } \\
\text { ditambah di sembilan } \\
\text { titik berbeda” }\end{array}$ & ditambah \\
\hline
\end{tabular}


Data (11) “Termasuk disiapkan rumah sakit rujukan nasional yakni RSUP dr.Soeradji Tirtonegoro Klaten"

Berdasarkan data (10) di atas, penulisan kata disiapkan kurang tepat. Kesalahan tersebut karena terjadi penggatian afiks yaitu prefiks (meng-) varian (men-) serta diikuti sufiks (-kan) dan peluluhan gugus konsonan /s/ yang digantikan dengan prefiks (di-) pada kata disiapkan sehingga kata tersebut seharusnya menjadi menyiapkan. Kata menyiapkan di sini memiliki makna menyediakan sesuatu yang dibutuhkan saat terjadi musibah covid seperti sekarang. Sehingga kalimat yang benar pada data (11) "Termasuk menyiapkan rumah sakit rujukan nasional yakni RSUP dr.Soeradji TirtonegoroKlaten"

Data (12) “Ke depannya akan ditambah di sembilan titik berbeda" .

Berdasarkan data (11) di atas, penulisan kata ditambah kurang tepat. Kesalahan tersebut karena terjadi penggatian afiks yaitu prefiks (meng-) varian (men-) serta diikuti sufiks (-i) dan peluluhan gugus konsonan /t/ yang digantikan dengan prefiks (di-) pada kata ditambah sehingga kata tersebut seharusnya menjadi menambahi. Kata menambahi memiliki makna menjadikan lebih banyak sesuai dengan yang diperlukan. Sehingga kalimat yang benar pada data (12) adalah "Ke depannya akan menambahi di sembilan titik berbeda".

\section{Peluluhan Bunyi yang Seharusnya Tidak Luluh}

Tabel 5. Peluluhan bunyi yang seharusnya tidak luluh pada berita Covid 19 Radar Solo

NO PUBLIKASI JUDUL BERITA KALIMAT

\begin{tabular}{l|llll} 
1. & $\begin{array}{l}\text { 15 Maret } \\
2020\end{array}$ & $\begin{array}{l}\text { Semalam, hotel merugi Rp } \\
1 \mathrm{M} \text {, berlakukan efisiensi, } \\
\text { cegah PHK }\end{array}$ & $\begin{array}{l}\text { "Kendati demikian, } \\
\text { Sistho mengklaim } \\
\text { kepercayaan tamu } \\
\text { masih tetap ada." }\end{array}$ & mengklaim \\
26 Maret & $\begin{array}{l}\text { Rakor Eksekusi Lahan } \\
\text { Sriwedari Tunggu KLB } \\
\text { Covid-19 Rampung }\end{array}$ & $\begin{array}{l}\text { "Anwar mengklaim } \\
\text { persiapan jumlah } \\
\text { aparat, pemindah } \\
\text { barang objek eksekusi, } \\
\text { dan gudang } \\
\text { penyimpanan..." }\end{array}$ & mengklaim \\
& & &
\end{tabular}

Data (13) “Kendati demikian, Sistho mengklaim kepercayaan tamu masih tetap ada."

Berdasarkan kalimat di atas penggunaan kata mengklaim kurang tepat karena terjadi peluluhan bunyi /e/ yang seharusnya tidak diluluhkan. Bentukan mengklaim terdapat peluluhan bunyi /e/ dimana seharusnya bunyi /e/ dituliskan dan tidak diluluhkan sehingga kata mengklaim seharusnya menjadi mengeklaim. Kata mengeklaim sendiri memiliki makna meminta atau menuntut pengakuan atas suatu fakta yang berhak memiliki atau mempunya. 
Sehingga kalimat yang benar pada data (13) adalah "Kendati demikian, Sistho mengeklaim kepercayaan tamu masih tetap ada."

Data (14) "Anwar mengklaim persiapan jumlah aparat, pemindah barang objek eksekusi, dan gudang penyimpanan..."

Berdasarkan kalimat di atas penggunaan kata mengklaim kurang tepat karena terjadi peluluhan bunyi /e/ yang seharusnya tidak diluluhkan. Bentukan mengklaim terdapat peluluhan bunyi /e/ dimana seharusnya bunyi /e/ dituliskan dan tidak diluluhkan sehingga kata mengklaim seharusnya menjadi mengeklaim. Kata mengeklaim sendiri memiliki makna meminta atau menuntut pengakuan atas suatu fakta yang berhak memiliki atau mempunya. Sehingga kalimat yang benar pada data (14) adalah "Anwar mengeklaim persiapan jumlah aparat, pemindah barang objek eksekusi, dan gudang penyimpanan... "

\section{KESIMPULAN}

Berdasarkan analisis data yang penulis lakukan, maka dapat disimpulkan bahwa analisis kesalahan berbahasa tataran morfologi pada berita Covid 19 Portal Radar Solo Edisi Maret 2020 terdapat 4 klasifikasi kesalahan, yaitu: (1) penghilangan afiks, (2) bunyi yang seharusnya luluh tidak diluluhkan, (3) penggunaan afiks yang tidak tepat, dan (4) peluluhan bunyi yang seharusnya tidak luluh.

Penghilangan afiks diklasifikasikan menjadi prefiks me-, ber-, dan sufiks -an, -kan. Pada penghilangan prefiks me- terdapat 4 kesalahan, meliputi kata tunggu, lacak, lakukan, ikuti. Dan prefiks ber- terdapat 1 kesalahan pada kata sinergi. Dan penghilangan sufiks -an terdapat 2 kesalahan, meliputi kata ruang dan barang dan penghilangan sufiks -kan terdapat 2 kesalahan meliputi kata diantar dan dimodifikasi.

Penulisan bunyi yang seharusnya luluh tidak diluluhkan terdapat 1 kesalahan, yaitu pada kata mempublikasikan. Kesalahan penggunaan afiks yang tidak tepat terdapat 2 kesalahan, yaitu penggunaan prefiks di- pada kata disiapkan dan ditambah. Kemudian yang terakhir adalah peluluhan bunyi yang seharusnya tidak luluh terdapat 2 kesalahan yaitu pada 2 kata mengklaim.

Berdasarkan analisis data, dapat ditarik simpulan bahwa portal daring Radar Solo dari segi tataran morfologi sudah dapat dikatakan cukup baik, karena hanya ditemukan 14 kesalahan dari 31 edisi.

\section{DAFTAR PUSTAKA}

Abdul, C. (2008). Morfologi Bahasa Indonesia (pendekatan Proses). Jakarta: Rinneka Cipta. Agustina, T., \& Oktavia, W. (2019). Analisis Kesalahan Berbahasa pada Bahan Ajar Kelas Menyimak Program BIPA IAIN Surakarta. Disastra: Jurnal Pendidikan Bahasa Dan Sastra Indonesia, 1(2), 146-156.

Dawa, A. B., Kaleka, L. B., \& Pingge, H. D. (2020). Analisis Kesalahan Berbahasa Pada Aspek Sintaksis Dalam Rubrik Opini Koran Victory News Edisi Januari 2019. Jurnal Penelitian Bahasa Dan Sastra, 1(1).

Febriyanti, N. E. (2020). Analisis Kesalahan Berbahasa pada Tajuk Rencana Koran Sindo. Hadi, I. P. (2009). Perkembangan teknologi komunikasi dalam era jurnalistik modern.

Scriptura, 3(1), 69-84.

Halim, S. (2015). Dasar-dasar Jurnalistik Televisi. Deepublish. 
Hapsoro, M. R. A. (n.d.). Analisis Kesalahan Berbahasa Morfologi pada Koran Timlo Edisi Agustus 2019.

Kusumaningrat, H., \& Kusumaningrat, P. (2009). Jurnalistik Teori \& Praktik. Bandung: PT Remaja Rosdakarya.

Nisa, K. (2018). Analisis Kesalahan Berbahasa Pada Berita Dalam Media Surat Kabar Sinar Indonesia Baru. Jurnal Bindo Sastra, 2(2), 218-224.

Nurwicaksono, B. D., \& Amelia, D. (2018). Analisis Kesalahan Berbahasa Indonesia pada Teks Ilmiah Mahasiswa. AKSIS: Jurnal Pendidikan Bahasa Dan Sastra Indonesia, 2(2), $138-153$.

Rahardi, F. (2006). Panduan lengkap menulis artikel, feature dan esai: modul dasar pelatihan jurnalistik bagi pemula dilengkapi dengan aneka contoh tulisan. Kawan Pustaka.

Sari, F. M. (2014). Analisis Penerapan Kode Etik Jurnalistik pada Harian Serambi Indonesia. Interaksi: Jurnal Ilmu Komunikasi, 3(2), 131-139.

Sari, K., \& Nurcahyo, R. J. (2019). Analisis Kesalahan Berbahasa Pada Majalah Toga Edisi III Bulan Desember Tabun 2018. Imajeri: Jurnal Pendidikan Bahasa Dan Sastra Indonesia, 2(1), 11-23.

Tarigan, H. G. (1990). Pengajaran Semantik. Bandung: Angkasa.

Wijayanti, D. R. (2014). Analisis Kesalahan Berbahasa Bidang Morfologi pada Karangan Narasi Siswa Kelas VII madrasah Tsanawiyah Muhammadiyah 1 Weleri Tahun Ajaran 2013/2014. Universitas Muhammadiyah Surakarta. 